\title{
Particulars and Universals in Aristotelian Substance Theory*
}

\section{Aristoteles Töz Öğretisinde Tekil ve Tümel}

\author{
Erman $\operatorname{Kar}^{1} \mathbb{D}$
}

"This study is basen on my PhD. thesis which is named Universality and Particularity of Aristotatelian Substances. Bu çalışma Aristotelesçi Tözlerin Tümellikleri ve Tekillikleri başlıklı doktora tezimi temel alarak üretilmiştir.

${ }^{1}$ (Assist. Prof.) Cankiri Karatekin University, Faculty of Letters, Department of Philosophy, Cankiri, Turkey

\section{ORCID: E.K. 0000-0002-6013-7805}

\section{Corresponding author/Sorumlu yazar:} Erman Kar

Cankiri Karatekin University, Faculty of Letters, Department of Philosophy, Cankiri, Turkey E-mail/E-posta: ermankar@karatekin.edu.tr

Submitted/Başvuru: 20.10.2021 Revision Requested/Revizyon Talebi: 03.01.2022

Last Revision Received/Son Revizyon: 08.01.2022

Accepted/Kabul: 10.01.2022

Citation/Atıf: Kar, Erman. "Particulars and Universals in Aristotelian Substance Theory." Felsefe Arkivi-Archives of Philosophy, 55 (2021): 35-48.

https://doi.org/10.26650/arcp.1012750

\section{ABSTRACT}

There has been contemporary disagreement about Aristotle`s substance theory. This disagreement has mainly focused on the problem of whether Aristotelian forms are particular or universal. According to the majority of the criteria which are stipulated by Aristotle in Metaphysics Zeta, forms are substances. However, Aristotle also explicitly outlines in the Zeta, and especially in chapters 13 and 16, that no universal can be a substance. At these points in his work, Aristotle should have been clearer regarding whether forms are universals or particulars. In terms of the conclusion of Chapter 13 of Zeta, as well as some other criteria, one may conclude that, if the substance is form, then it should be particular. There are many instances, however, where Aristotle says that since universals are knowable, particulars cannot be known. It seems that if substances are particulars, it is hard to see how they can be knowable. Furthermore, if they are universal, it is hard to say whether particular forms are substances. Since Aristotle never mentioned whether forms could be both universal and particular, this causes difficulties. To examine this problem in more depth, I will not only analyse some textual evidence which is often used to justify the view that forms are universal, but also some textual evidence which is used to justify the view that forms are particular. In so doing, I will also identify some possible solutions regarding the problem of the status of forms in Aristotle's substance theory. Lastly, I will suggest that individual forms are substances because they are instances of universals and, hence, may be knowable. I will support my view by employing the neo-Aristotelian substance theory posited by Jonathan Lowe; namely, the "Four-Category Ontology." . Keywords: Aristotle, Substance, Form, Particulars, Universals

\section{öz}

Aristoteles'in töz anlayışı güncel bir anlaşmazlığa sebep olmaktadır. Bu anlaşmazlık temel olarak Aristoteles tözlerinin tekil mi yoksa tümel mi olduğu problemine dayanmaktadır. Aristoteles'in Metafizik Zeta'da ortaya koyduğu ölçütlerin çoğuna göre form töz olarak tanımlanır. Öte yandan Aristoteles, Zeta ve özellikle 13. ve 16. bölümlerde hiçbir tümelin töz olamayacağını açıç̧a belirtir. Zeta boyunca Aristoteles'in formun tekil mi yoksa tümel mi olduğu konusunda açık olmadığı da analiz edilebilir. Metafizik Zeta'nın on üçüncü bölümünden çıkarılacak sonuç gereğince eğer form töz ise onun aynı zamanda bireysel olması beklenmektedir. Ancak, Aristoteles'in öğretisinde tümeller bilinebilir olarak tanımlandıkları için tekillerin bilinemeyeceğini söylediği birçok örnek vardır. Bu bakımdan töz bir yandan 
tekil ise, tözlerin bilinebilirliği konusunda ciddi problemler ortaya çıkmaktadır. Bu problemler özetle Aristoteles'in formun hem tümel hem de tikel olabileceğini açıkça belirtmemesinden de kaynaklanmaktadır. Problemi daha net analiz edebilmek üzere bu çalışma Aristoteles metinlerinde formların dolayısıyla tözün tikel ve tümel olduğunun vurgulandığı pasajları incelemeyi, ve tekil şeylerin tümellerin birer örnekleri olarak hem töz olabileceği hem de bilinebilir şeyler olabileceklerini ileri sürmeyi amaçlamaktadır. Bu iddia Jonathan Lowe tarafından ortaya atılan Dört-Kategori Ontoloji isimli çalışma ile desteklenecektir.

Anahtar Kelimeler: Aristoteles, Töz, Form, Tekil, Tümel

\section{Introduction}

Metaphysics Zeta, which is devoted to the notion of substance, has been at the center of heated debate over the last fifty years, and this problem has been at the center of a huge controversy. ${ }^{1}$ It could be claimed that this debate addresses two different specific problems in Aristotle's ontology. On the one hand, scholars mainly accept that the general conclusion of Zeta is that the form of sensible objects is primary substances. However, this conclusion is a departure from Aristotle's ontology in the Categories, where the primary substances are sensible objects themselves. The tension between these different results has been discussed among contemporary Aristotelian scholars. Some claim that Aristotle is inconsistent since he claims different results for the same problem. ${ }^{2}$ Some others say that Aristotle's theory is not inconsistent, because Aristotle addresses the same issue, but with a different methodology ${ }^{3}$.

There is another contemporary debate which is related to the first discussion. This problem can be sketched as follows: if it is true that Aristotelian substances are forms of the sensible objects, as he writes in Zeta, the question arises over whether these forms or substances are universal or particular? This is another issue but is still related to the first problem with his substance theory. On the one hand Aristotle explicitly writes that substances are particulars since he defines substances by the notion of tode $t i^{4}$. So, substances must be "separate" (chôriston) and "some this" (tode ti). On the other hand, since Aristotle writes that the definition is of universals and he explicitly claims that knowability belongs to substance, they are universals. ${ }^{5}$ Because if they are particulars, it is impossible to define and know particular substances. It is obvious that this main problem over whether Aristotelian substances are universal or particular questions the relation between universality and particularity. My main suggestion in this paper is that Aristotelian substances are not only particular but are also universal since the dualism between

1 Gabriele Galluzzo, “Aquinas's Interpretation of Aristotle's Metaphysics, Book Z.” Recherches de Theologie et Philosophie Medievales (2007), 43.

2 Wallace, Aristotle's Psychology, (Cambridge: The University Press, 1882), 39.

3 For example, Wedin (2002) claims that in the Categories Aristotle asks what entities are the primary substances and/ or what entities are the fundamental items. On the other hand, in the Metaphysics, some different kinds of questions are raised over what is the substance of the object in the Categories, or what is the substance of the sensible objects, but in the Metaphysics, Aristotle analyses sensible objects in terms of matter and form. He claims that form is the substance of sensible objects, or it is the thing which accounts for the substantiality of sensible objects.

4 Aristotle, Metaphysics, translated by David Bostock (Oxford: Clarendon Press, 1994), 1029a28.

5 "What sorts of parts belong to the form and what sort not to the form, but to the concrete thing. Yet if this is not plain it is not possible to define anything; for definition is of the universal and of the form" In addition, Aristotle denies the definability of particulars in Z15 (Aristotle, Metaphysics, 1039 b27 and 1036a16). 
universal and particular in his ontology is not particularly strong. Because of this, I will suggest that the relation between universals and particulars is symmetrical rather than asymmetrical based on the main idea of Four-Category Ontology by Jonathan Lowe. This makes universals and particulars mutually-dependent entities. ${ }^{6}$ This relation is the reason why it could be claimed that Aristotelian substances are both particulars and universals. It is useful to discuss first of all some textual evidence on the particularity of substances and the universality of substances in Zeta. Secondly, I will try to show why we need to analyse the main problem by claiming the dependency of universal and particular entities in Aristotle, hence I am able to claim that Aristotelian substances are both particulars and universals. Lastly, in terms of the main problem in Aristotelian substance theory, I will suggest, by inspiring the ontology of Jonathan Lowe, that substantiality of universals and particulars is possible since there is a symmetrical relation between them.

\section{Particularity of Aristotelian Substances}

Aristotle explicitly says that nothing said universally can be substances. The following question arises: what does he mean by 'said universally' in this case? Aristotle does not have a definition of universal and particular in Metaphysics. However, what he clearly means is that universals are predicated on many things, but a substance cannot be predicated on something. Aristotle uses the same definition of himself which is mentioned in De Interpretatione. Universals cannot exist separately from particulars, which means there is no such thing as 'one' over many'. This supports the idea of 'being numerically one' for substances, and Aristotle says that universals cannot be substances, since they lack the numeric unity required of substances. Essence or form are able to be numerically one without contradiction. This assumes that a substance must be one or individual.

For it seems impossible that any universal term should be the name of a substance. For primary substance is that kind of substance which is peculiar to an individual, which does not belong to anything else; but the universal is common, since that is called universal which naturally belongs to more than one thing. Of which individual then will be the substance? Either of all or of none. But it cannot be the substance of all; and if it is to be the substance of one, this one will be the others also; for things whose substance is one and whose essence is one and themselves also one. ${ }^{8}$

This passage eliminates the substantiality of species and universals. If something belongs to more than one thing (such as man, which describes both Socrates and Callias), one could not

6 Mutual-dependency is a concept that I named for the ontological dependency between particulars and universals. It is a concept for mentioning the ontological dependency is not one-way between universal and particular entities.

7 The supporters of particular forms claim that particular forms of sensible objects do not owe their particularity to anything but themselves. In this sense, their particularity is basic and primitive. (Galluzzo, 'Aquinas's Interpretation of Aristotle's Metaphysics, Book Z.'.472).

8 Aristotle, Metaphysics, $1038 \mathrm{~b} 8-15$. 
both say that that thing is one (since it belongs to more than one thing) and that that thing's essence is one (since that thing and its essence are the same) ${ }^{9}$. If a universal were the substance of these things, then it would have one substance and should be one. Thus, no "one", over many, can be substance. Moreover, a universal is predicable of some subjects, whilst substance means that which is not predicable of a subject. ${ }^{10}$

On the other hand, Aristotle claims that many particulars can share the same form, though he claims that nothing said universally can be a substance in Zeta 13 and $16 .{ }^{11}$ The question which arises at this point is: how can many things have the same essence if the essence is not a universal? In other words, the problem is this: if forms are universal, there is a sense in which it is true to say that the different particular objects belonging to a natural kind possess just one form. If there is no sense in which this can be truly asserted by contrast, then the forms are particulars. ${ }^{12}$ Individuals (kat hekaston) or what ontologically basic signify particulars (e.g. "this individual man" (i.e. Socrates) or "this horse") in the Categories and the forms (eidos) of these particulars in Metaphysics Zeta. Primarily, though, he states that which is universal (katholou) is the most intelligible. However, for primary substances, Aristotle identifies both form and particular objects as tode $t i$, and it seems that both can be substances since as it is mentioned, tode $t i$ is one of the characteristics of substances.

In the Categories, Aristotle describes tode ti as being particular, and he maintains explicitly the same definition in the Metaphysics Zeta. So, there are some comments to make on this issue. First, it is true that in the same sense both forms and composites are tode ti, and naturally, it is confirmed that forms are particulars, rather than universals. However, it may be claimed that concrete particulars can be identified as tode ti in different ways, as Aristotle says in the Categories, with composites having the priority for being tode $t$, but the form is a kind of fully determinate position in this case.

It is the general claim of Aristotle on substances that a substance must be one in number, and this is the reason that a universal cannot be a substance. This is because universals have two characteristics: first, they are predicated of many particulars, and they are composed of other universals. ${ }^{13}$ This means that if an entity can be predicated of more than one object it would not be one in number. Aristotle describes what universals and particulars are in De Interpretatione, where he writes: "I call universal that which is by its nature predicated of a number of things, and particular that which is not; man, for instance, is a universal, Callias particular." ${ }^{14}$ Universals are not one in the pertinent way, and they do not fit the characteristics of tode ti, hence they are not substances.

9 "Each thing and its essence are one and the same in no merely accidental way" (Aristotle, Metaphysics, 1031b20).

10 Aristotle, Metaphysics, 1038b135-16.

11 Aristotle, Metaphysics, $1034 \mathrm{a} 5$ and $1058 \mathrm{~b} 5$.

12 Galluzzo, 'Aquinas's Interpretation of Aristotle's Metaphysics, Book Z.' 471.

13 Edward, C. Halper, "Aristotle's Solution of the Problem of Sensible Substance", Journal

of Philosophy: XXXIV (1987), 670.

14 Aristotle, Categories, and De Interpretatione, translated by Ackrill J.L.(Oxford: Clarendon Press, 1963), 17 a36. 
Lastly, whether the thing and its essence are equal to or different from each other is the main discussion in Zeta 6, and Aristotle reaches a conclusion that the essence of a thing and the thing itself are equal. For example, Socrates is nothing other than its essence. It could be asked at this point whether essence is equal to the composite or the form. Aristotle writes:

We must inquire whether each thing and its essence are the same or different. This is of some use for the inquiry concerning substance; for each thing is thought to be not different from its substance, and the essence is said to be the substance of each thing. ${ }^{15}$

This statement obviously means that each thing is not distinct from its essence, or in other words, there is nothing in essences or forms apart from individual entities. For instance, Socrates is an instance of mankind, but he does not seem to be the same as mankind (if we say that the human being, taken universally, is the essence of Socrates). ${ }^{16}$ In addition, in terms of the claim of the equality of essence, Socrates has to be the same as "what Socrates is" exactly, and it seems that it is nothing apart from Socrates himself. However, when one says that Socrates is a man, this statement is not referring to Socrates (as a particular concrete) at all. In this case, Socrates refers to the essence that all men share. ${ }^{17}$ For example, if this apple is the same as the substance of an apple, or if Socrates is the same as the substance of Socrates, then we may add that this apple is one of the instances of fruit and that Socrates is one of the instances of man. In terms of the equality of essence, if something is the same as its essence, we could not say that the apple is identical to "fruit", nor could we say that Socrates is identical to "man". It is what it is (it has its own essence or form), and he is what he is (Socrates has his own, particular form).

It is useful to look at supporters of the idea of particularity of Aristotelian substances. For example, Hartman (1976), suggests that particular forms meet all criteria for being substance in Aristotle's theory since each material object has-and is identical to-its own particular form. In Zeta 17, Aristotle identifies substance as a principle and cause. He outlines that substances/ forms are the reasons why something is itself, for example, why some stones and bricks are a hous $\mathrm{e}^{18}$. Hartman, also, claims that in this case, Aristotle addresses the particular forms in terms of why the matter is some particular thing or what makes a particular is a particular. ${ }^{19}$ The form is substance, and it is substrate to matter since it persists, and it is the reason for the unity and identity of material things, through the material change.

Furthermore, Frede and Patzig (1998) claim that Aristotelian forms are particular. In terms of the definability and knowability of substantial forms, their theory seems incompatible, since, as aforementioned, knowledge and definition of universal and substantial forms are the principles of knowledge, hence, a substantial form is universal. These statements cause difficulty for the

15 Aristotle, Metaphysics, 1031a15.

16 S. Marc Cohen, "Individual and Essence in Aristotle’s Metaphysics", Paideia: Special Aristotle Edition, (1978), 75.

17 Cohen, "Individual and Essence in Aristotle's Metaphysics", 82.

18 Aristotle, Metaphysics, 141a22.

19 Aristotle, Metaphysics, 141a32. 
knowability of particular substances, if it is said that they are particular. Frede and Patzig have an approach for this problem: namely, a nominalist theory on the knowability of particular substances. They claim that "definition is predicated universally of many particulars, rather than definition is of universal. ${ }^{20}$ In other words, particulars can be known via universals which are predicated of them, but at this point another question arises: how can we manage to identify particular forms at a given time? Frede (1987) writes that:

"They differ from each other by being realized in different matters, and by being the ultimate subject of different properties. A particular form can be identified through time by its continuous history of being realized now in this, and now in that matter, of now being the subject of these and then being the subject of those properties". ${ }^{21}$

\section{Universality of Aristotelian Substances}

Although Aristotle never, explicitly, claims that forms are universal, there are some reasons to think that he holds this view. The main reason for this is that forms are able to satisfy Aristotle's demand of knowledge and definition. He says that forms are knowable and definable ${ }^{22}$, and claims that knowledge and definition of are universal ${ }^{23}$. This follows the view that forms are universal. Moreover, in Zeta 15, Aristotle explicitly denies the definability of perishable things. ${ }^{24}$ This claim means that there is no scientific knowledge or demonstration of perishable things, because they have matter, and destructible things cannot have a definition. The problem can be shown with the following premises: (1) particulars are indefinable (because of their matter); (2) definitions are not of concrete particular things but of their forms; (3) form is the object of knowledge; (4) nevertheless, we cannot say that forms are particulars because of premise (1). Thus, it seems that forms are universal. One may reach this conclusion in terms of the features of knowable and definable things.

In Beta, Aristotle says that if the principles are individuals, since knowledge is universal, then the principles will not be knowable. If principles are to be knowable, but individuals, then there must be universal principles which are knowable and prior to the individual principles. And the principles, which Aristotle has in mind, are substantial forms. Furthermore, Aristotle explicitly states that perishability is the reason for why sensible particulars cannot be the object of knowledge. Does it make individual forms/or principles unknowable as well? Heineman says that

20 M. Frede, and G. Patzig,. 'Aristoteles, Metaphysik Z, Text, Ubersetzung und Kommentar, (2 vols. Munich: Beck', 1988), 55, cited in T. Scaltsas, Substances and Universals in Aristotle's Metaphysics. (New York: Cornell University Press. 2010) 93.

21 M. Frede, M. "Substance in Aristotle's Metaphysics." In: Essays in Ancient Philosophy, Ed. M. Frede (Oxford: Oxford University Press, 1987) 78.

22 Aristotle, Metaphysics, $1036 \mathrm{a} 26$.

23 "There is nothing apart from individual things, and the individuals are infinite in number, how is it possible to get knowledge of the infinite individuals? For all things that we know in so far as they have some unity and identity, and in so far as some attribute belongs to them universally" (Aristotle, Metaphysics, 999a25-28)

24 Aristotle, Metaphysics, $1039 \mathrm{~b} 27$. 
if perishability is a sufficient reason for concluding that perceptible substances are not objects of knowledge it would also appear to be a sufficient reason for concluding that their forms cannot be objects of knowledge as well. ${ }^{25}$ Additionally, in Zeta 10, Aristotle discusses the problem of definition and formula, and the main question in this chapter is whether composites of form and matter have a formula or a definition. He insists that the (3) formula belongs to only form, rather than matter. During the same chapter, he many times writes that knowledge and definition are universal. In this case, naturally it could be claimed that (4) form is universal, otherwise it could be hard to say that it has a definition.

First of all, as previously mentioned, Aristotle claims that form is the essence of sensible concrete particulars. However, when Aristotle discusses the problem of the definition of sensible substances, he generally has two different identifications. The first is that definition is universal, and definition is supposed to reflect perfectly the content of an essence, since what the essence is is what the thing is. The definition of a thing corresponds to the definition of the essence of that thing. So, if it is true that form is the essence of substances, how could it be claimed that the form is particular rather than universal? In this case, either Aristotle should have abandoned one of these descriptions, or he should not have equalized form and essence.

Second of all, Aristotle declares that essence belongs to nothing which is not a species of genus. ${ }^{26}$ The main reason for this claim is that he thinks species is primary, since they are not said of something else. In this case, Aristotle writes that that which is one can have an essence, and only species is one, because it has no parts, and the formula of what has no parts contains no addition. ${ }^{27}$ The formula of species is what makes species one. For the supporter of universal forms, for example Modrak (1979), the most obvious reason is that Aristotle claims that species are substances, since they are one in formula. The question arises over being one in number. Species obviously are not one in number, but one in formula. However, what Aristotelian substance requests is not (only) being one in formula or definition, but one in number, since tode $t i$, by definition, corresponds to one in number. In the Aristotelian context, being one is used in many ways. However, it is obvious that he equates individual and one in number, and, on the other side, one in formula and universality. ${ }^{28}$ It could be claimed that these equations cause the complexity over whether forms are universal or particular.

Modrak (1979) has a formulation for this complexity. He claims that there are two kinds of universals, namely properties and substance types (or substantial universals). What Aristotle means, in $\mathrm{Z13}$, by the claim that no universal can be a substance is that no property-universals can be a substance, but this does not change the substance-hood of substantial kinds (e.g. species, or genus). He supported this idea with the distinction between primary and secondary substances. For him, although the conception of primary and secondary substances is not found in the

25 R. Heinaman, R. "Knowledge Of Substance In Aristotle". The Journal of Hellenic Studies: 101. (1981), 77.

26 Aristotle, Metaphysics, 1030a11.

27 Halper, 'Aristotle's Solution of the Problem of Sensible Substance', 667.

28 Aristotle, Metaphysics, $999 \mathrm{b33}$. 
Metaphysics, Aristotle holds the idea that a species of composite particulars is form. ${ }^{29}$ According to this method of Aristotle, Modrak claims that it should be accepted what no universal is a substance means, indeed, is that no property-universal is a substance.

I disagree with this idea, since Aristotle describes in the Categories something which is said of a subject for both secondary substances and properties. The examples he uses for this issue can show this explicitly, e.g. man-animal. This means that the relation of said of is not used by Aristotle in the narrower sense, but it obviously includes both properties [they are both said of a subject and in a subject, e.g. redness] and secondary substances. What I mean by this is that, when Aristotle claims that no universal can be a substance, he does not mention, explicitly or implicitly, whether these kinds of universals are essential (e.g. species, genus) or accidental (e.g. qualities, quantities).

Lastly, Aristotle discusses the possibility of the generation of form from Zeta 7 to 9, and he asks whether form is generated in the generation of composites. He gives an example to make clear this problem, which is that man generates man. On the other hand, in this case, it could be said that forms are ingenerated or the form pre-exists the generation ${ }^{30}$, and this claim makes forms universal. This is so because, if my form is particular, rather than universal, it is not possible to get it from my father. If Aristotle is right to claim that man generates man, then I need to get my form from my father, and this makes my form non-unique. Halper (1987) claims in this case that Aristotle would need to abandon his naturalistic account of generation. Otherwise, there is no room to claim particularity of substances.

In general, it should be outlined that supporters of the universal forms do not suppose to say that Aristotle is a Platonist. In other words, they, also, reject the idea of separated forms. They mainly claim that forms can only exist as the form of particular sensible objects. In this case, they seem to accept that all sensible objects have their own forms, in which aspect they claim that forms are universal. Supporters of universal forms claim that for each species, e.g. man, there is only one substantial form, and this substantial form is individualised by being instantiated in different material subjects. This means that form is universal, and only this universal form (e.g. man) can be replicated in different bits of matter. ${ }^{31}$ In this case also, they explicitly specify their opinion on the problem of individuation, and obviously matter provides a positive argument. This is because what makes a sensible object a particular is its matter, rather than its form, which is shared by other particular sensible objects.

\section{Symmetrical Relation between Universals and Particulars}

In the Metaphysics, Aristotle asks two key questions. The first is what kind of science investigates being as being, and he wrote that "there is a science which investigates being as being

29 D.K.W. Modrak, 'Forms, Types and Tokens in Aristotle's Metaphysics'. Journal of the History of Philosophy. (1979) 17 (4), 372 .

30 Halper, 'Aristotle's Solution of the Problem of Sensible Substance' .668.

31 Galluzzo 'Aquinas's Interpretation of Aristotle’s Metaphysics, Book Z.' 471. 
and the attributes which belong to this in virtue of its own nature". ${ }^{32}$ The second and most important question is what is being? Aristotle asks this question in different ways; what are the principles or causes, or what kinds of entities exist? It could be said that Aristotle accepts that being in itself (being as being) can be known and there is such a science for investigating the kinds of being, and being itself. At the beginning of Zeta, Aristotle writes that

\footnotetext{
"There are several senses in which a thing may be said to be, for in one sense it means what a thing is or a 'this', and in another sense it means that a thing is of a certain quality or quantity or has some such predicate asserted of it. Although 'being' has all these senses, obviously that which is primary is the 'what', which indicates the substance of the thing". ${ }^{33}$
}

The question now arises of how neo-Aristotelian theories in general, and the Four-Category Ontology in particular deal with the status of being and the possibility of its knowledge. So, it is useful to mention firstly why one of the very critical problems of Aristotelian substance theory, which is whether Aristotelian substances are universal or particular, needs a neo-Aristotelian approach.

That substances are both universal and particular is the main argument of this paper. However, several problems arise if it is claimed that forms are both universal and particular. First, Aristotle never explicitly or implicitly claimed this view, and second, he did not have a theory of universals apart from his substance theory. The latter is quite problematic, since I cannot show directly why and how Aristotelian substances are both universal and particular. In definition, Aristotle was not clear about the concepts of particular and universal, and this is the second reason why it is necessary to interpret his substance theory with a contemporary approach. This new ontology should accept the existence of universals, and in definition, this ontology should be discussed in terms of particulars and universals being different entities, although they are both substantial.

Another reason is the ambiguity of the ontological relation between universal and particular in Aristotelian ontology. The most explicit passage referring to the Aristotelian universal, particular and their relationship is in the Categories. However, the phrases said of and being in relation as an explanation for the universal/particular distinction has many problems. In the Four-Category Ontology, Lowe uses other phrases rather than those two: instantiation and characterization, respectively. In a few words, therefore, the problem of whether Aristotelian substances are particular or universal requires the analysis of three entities; substance (form), particulars, and universals. In terms of my approach, substances are both universal and particular, I believe that it is necessary to take into account a neo-Aristotelian substance theory. Such a theory should include a substantial role for both universals and particulars, the acceptable and arguable relationships between universals and particulars, and the proper frame for the properties and their bearers: substances.

32 Aristotle, Metaphysics, 1003a22.

33 Aristotle, Metaphysics, 1028a9. 
Moreover, as was stated above, Aristotelian ontology does not have separate substance and universal theories. Aristotle's ontology of substance and universality are discussed with two different conceptions. The first is the hylemorphic conception of Aristotle's Metaphysics, specifically in Zeta, and the second is the four-fold ontology of the Categories. Aristotle never articulated these conceptions. However, in Zeta, he says that primary being has matter and form and that the concrete object is the combination of matter and form. Historically, this approach is called hylemorphism. Aristotle classifies entities under four different groups and this approach is referred to as the four-fold ontology. The Four-Category Ontology was inspired by the ontology of the Categories. On the one hand, in the Categories Aristotle indicates two different relations, or it could be said that they are technical notions; namely; said of a subject and being in a subject. ${ }^{34}$ On the other hand, the main characteristic of the new ontology is that these relations, or notions, are explained as, respectively, instantiation and characterization. These will be discussed in the next chapter, but briefly Lowe explains why he needed to change this terminology;
"Since the Aristotelian terminology of being said of and being in is perhaps less than fully perspicuous, with the former suggesting a linguistic relation and the latter seemingly having only a metaphorical sense, I prefer to use a different terminology; that of instantiation and characterization." 35

In order to address the main problem of this paper, if it is considered the hylemorphic approach of Aristotle, the main question, whether forms are universal or particular, is still problematic. Because if it is said that particular concretes have both matter and form (conceived as universal), it is hard to see how a particular piece of matter has this universal form ontologically. Moreover, if it is said that this particular piece of matter has its own form, this causes other problems epistemologically. This is the reason why this key problem cannot be solved by only focusing on Metaphysics Zeta. However, the Four-Category Ontology offers the notion that there are two forms: universal form and the particularized form instantiating that universal, but this ontology also offers the possibility that universal forms are ontologically posterior to particulars. It seems that this is the reason why this ontology claims that there are no uninstantiated universals. Although universals are perfectly real, they are perhaps best seen as being abstractions from, or invariants across, particulars. ${ }^{36}$

Generally, it can be said that Aristotle's forms are universal if they are regarded as somehow sharable and repeatable entities, whereas they are particular if they are not sharable and repeatable, but rather peculiar to individual objects. Supporters of the universality of forms and particularity of forms accept that each individual belonging to a natural kind has a form distinct from the form of another individual of the same kind. However, they disagree on what makes such a form particular, and they claim that it is not the form but the matter. On the other hand, if it is claimed that form is particular, they could be joined independently by this or that piece of

34 Jonathan Lowe, The Four-Category Ontology. (Oxford: Clarendon Press, 2006). 70.

35 Lowe, The Four-Category Ontology, 70

36 Jonathan Lowe, A Neo-Aristotelian Substance Ontology: Neither Relational nor Constituent. Ed.Tahko, Tuomas

E. ed. Contemporary Aristotelian Metaphysics.(Cambridge: Cambridge University Press, 2012), 245. 
matter, since they are unrepeatable entities. ${ }^{37}$ It is the main claim of this paper that the problem over whether Aristotelian forms are universal or particular can be solved by analysing the relation between universals and particulars, and it can be claimed that this relation is symmetrical rather than asymmetrical. I will now try to show what this means.

According to traditional and contemporary interpretations, the relationship between universal and particular can be identified in different senses. The former claims that there is an asymmetrical relationship between universal and particular entities. This means that a universal entity ontologically depends on its instance, but not vice versa. In other words, particular entities do not have to depend on their kinds. This interpretation is obviously the main conclusion of the Aristotelian ontology, since, as he mentions, particular entities are more real than universal entities because of this asymmetrical relationship. The definition of primary substances in the Categories explicitly addresses this result, because "they are neither said of a subject nor in a subject" this means they are independent entities and are more real than any other kinds of entities (e.g. non-substances entities, or substantial universals). ${ }^{38} \mathrm{I}$ strongly disagree with this interpretation, since I believe that the dependence is symmetrical in a sense, and this relationship makes both universal kinds and their instances substantial. According to Lowe, this is summarised as follows:

\begin{abstract}
"I should stress that my 'Aristotelianism' does not involve the notion that individuals or particulars are in any sense 'more real' than sorts or kinds, or that they somehow enjoy a more fundamental species of existence - for 'exist', I believe, is perfectly univocal. Individuals may indeed be 'ontologically prior' to the sorts that they instantiate, in the sense that the existence of the individuals grounds the existence of their sorts, but not vice versa. But we can acknowledge such 'existential grounding' while at the same time insisting that individuals are no less essentially individuals of some sort than sorts are essentially sorts of individuals. The notion of ontological dependency is a complex and multifaceted one, capable of accommodating both the thought that sorts are, in one sense, asymmetrically dependent for their existence upon their individual instances, and the thought that, in another sense, there is a symmetrical essential dependency between individuals and sorts." ${ }^{39}$
\end{abstract}

However, in Aristotelian ontology, particulars enjoy priority over universals. In other words, particulars can exist independently from universals or non-substantial categories or entities, while universals and non-substantial entities must depend on particulars for their existence. This is what Aristotle explicitly claims in the Categories, and some scholars have called this ontological priority for particulars, or ontological dependence for universals, an asymmetrical relation. Therefore, universals depend on particulars, but not vice versa. According to this asymmetrical relation of universals and particulars, Aristotle himself has drawn a picture of dualism between these two entities, and this picture does not seem very different from the Platonic view of universals. If

37 Galluzzo, 'Aquinas's Interpretation of Aristotle's Metaphysics, Book Z' 425.

38 Aristotle, Categories, and De Interpretatione ,2a13.

39 Jonathan Lowe, More Kinds of Being: A Further Study of Individuation, Identity, and the Logic of Sortal Term. (Chichester: Blackwell, 2009), 162-163. 
some insist that the relation is asymmetrical, and Aristotelian forms are particular, it does not rescue him from being inconsistent. On the other hand, my essential interpretation suggests that there is no such kind of sharp dualism between particulars and universals in Aristotelian ontology, since the most knowable (universals) and the most real (particulars) are mutuallydependent entities.

The argument that the relation between particulars and universals is asymmetrical can be rejected. Obviously, claiming this means that the relation is symmetrical, or, in other words, particulars are dependent on universals as well. By definition, being a particular entity requires being a particular entity of a certain species or class (i.e. all particulars are instances of a universal). It is the general assumption that particulars and universals should be mutually-dependent entities, and it can be claimed that Aristotelian substances could be both universal and particulars. Owen (1965) claims that "Aristotle's most powerful and influential analysis of substance - that is, of the general nature of individuals - begins by requiring that a substance be both a this and what is $i$, tode $t i$ and $t i$ esti" ${ }^{\prime \prime 0}$. "A this" is always a member of a class, rather than against that class. The question "What is it?", on the other hand, introduces a classification, or a definition of something. ${ }^{41}$

\section{Conclusion}

It is the traditional tendency that universals and all other categories or entities in Aristotle's ontology, especially the ontology in the Categories, are dependent on primary substances or particular entities. However, I argue that in the Categories, according to Aristotle's essentialist approach, primary substances also depend on secondary substances, so there is mutual-dependency between primary and secondary substances (or substantial particulars and substantial universals). Aristotle never discusses this issue in the Categories, but he argues implicitly that the question of what primary substances are, indeed, corresponds to secondary substances e.g. the species of primary substances. At this point, it is useful to mention again why the Four-Category Ontology is quite significant when discussing the status of Aristotelian substances, especially for the view that both particular and universal entities are substantial. Furthermore, Lowe claims that it is useful to distinguish substantial entities as substantial particulars and substantial universals rather than primary and secondary substances, because of their ontological relation. In a realist sense, universal entities depend on particular entities, because there is no un-instantiated universal entity. In an essentialist sense, however, particular entities depend on their kinds, necessarily, because they are nothing but instances of their kinds.

In general, the main claim of this paper is to find an alternative solution to the question of whether Aristotelian substances or forms are universals or particulars. For the formulation of this problem and as a methodology, I follow two basic steps. According to the first, namely the conceptual base of the problem, three concepts of the main problem have been analysed in terms of both Aristotelian and Lowean ontologies. These terms are form, universal and particular.

40 Aristotle, Metaphysics, 1028a11.

41 Lowe, The Four-Category Ontology, 2. 
According to the second method, what I call the historical base of the problem, I analyse the problem in relation to these three concepts in terms of both the historical background and the contemporary approach.

All in all, particular entities are instances of their kinds, e.g., Socrates is a particular entity and he is an instance of a human being. Particular substantial forms are particular entities, and they are instances of universal substantial forms. By definition, there is a mutual-dependency between particular forms and universal forms, in other words, the ontological relationship between them is symmetrical rather than asymmetrical. In terms of the traditional approach, however, primary substances, or particular entities, are independent, and all other entities, including their substantial kinds, are dependent on them. However, I discuss the problem using another approach, and according to this approach not only are kinds dependent on their instances, but those instances also depend on their kinds. This mutual-dependency corresponds to the arguments that primary substances as particulars are instances of substantial universals; hence, Aristotelian forms are both universal and particular.

Peer-review: Externally peer-reviewed.

Conflict of Interest: The author has no conflict of interest to declare.

Grant Support: The author declared that this study has received no financial support.

Hakem Değerlendirmesi: Dış bağımsız.

Çıkar Çatışması: Yazar çıkar çatıșması bildirmemiștir.

Finansal Destek: Yazar bu çalışma için finansal destek almadığını beyan etmiştir.

\section{References / Kaynaklar}

Aristotle. Metaphysics. Translated by David Bostock. Oxford: Clarendon Press, 1994.

Aristotle. Categories, and De Interpretatione. Translated by Ackrill J.L. Oxford: Clarendon Press, 1963.

Cohen, S. Marc. "Individual and Essence in Aristotle's Metaphysics". Paideia: Special Aristotle Edition. (1978): 75-85.

Frede, M. "Substance in Aristotle's Metaphysics." In: Essays in Ancient Philosophy, M. Frede (ed.). Oxford: Oxford University Press (1987): 72-80.

Frede, M. and Patzig, G.. Aristoteles, Metaphysik Z, Text, Ubersetzung und Kommentar, 2 vols. Munich: Beck, 1988.

Galluzzo, Gabriele. “Aquinas's Interpretation of Aristotle's Metaphysics, Book Z.” Recherches de Theologie et Philosophie Medievales: Vol.74(2). (2007): 423-481.

Halper, Edward, C. "Aristotle's Solution of the Problem of Sensible Substance". Journal

of Philosophy: XXXIV. (1987): 666-672.

Heinaman, R. "Knowledge of Substance In Aristotle". The Journal of Hellenic Studies: 101. (1981): 63-77.

Lowe, E.J. The Four-Category Ontology. Oxford: Clarendon Press. 2006

Lowe, E.J. More Kinds of Being: A Further Study of Individuation, Identity, and the Logic of Sortal Term. Chichester: Blackwell. 2009

Lowe, E.J. A Neo-Aristotelian Substance Ontology: Neither Relational nor Constituent. In: Tahko, Tuomas E. ed. Contemporary Aristotelian Metaphysics. 229-248. Cambridge: Cambridge University Press, 2012. 
Modrak, D. K. W. 'Forms, Types and Tokens in Aristotle's Metaphysics'. Journal of the History of Philosophy. 17 (4), (1979): 371-381.

Owen, G.E.L. "Inherence” Phronesis: 10(1). (1965): 97-105.

Scaltsas, T. Substances and Universals in Aristotle's Metaphysics. New York: Cornell University Press. 2010.

Wallace, E. Aristotle's Psychology. Cambridge: The University Press. 1882

Wedin, Michael V. Aristotle's Theory Of Substance. Oxford: Oxford University Press. 2000. 